\title{
İnme Hastalarında Tam Kan Sayımı Parametreleri Fonksiyonel Seviyeyi Gösterir mi?
}

\author{
Do Complete Blood Count Parameters Show a Functional Level in Stroke Patients? \\ Tuba Tülay KOCA ${ }^{1}$, Aydın ARSLAN ${ }^{2}$ \\ ${ }^{1}$ Dr. Öğr. Üyesi. Kahramanmaraş Sütçü İmam Üniversitesi Tip Fakültesi, Fiziksel Tip ve Rehabilitasyon AD, KAHRAMANMARAŞ \\ ${ }^{2}$ Dr. Öğr. Üyesi. İstanbul Gelişim Üniversitesi Sağlık Bilimleri Fakültesi, Ortopedi ve Travmatoloji AD, İSTANBUL
}

\section{Öz}

Amaç: İnflamasyon, inme patogenezinde çok önemli bir role sahiptir, son yıllarda tam kan parametre ve türevleri çeşitli hastalıkların seyrinde kötü prognoz kriteri olarak yol gösterici bulunmaktadır. Burada çeşitli tam kan parametre ve türevlerinin inmeli hastaların fonksiyonel seviyeleriyle ilişkisini ortaya koymayı amaçladık.

Gereç ve Yöntem: Kliniğimize 2016-2017 yılları arasında yatarak tedavi gören inme tanılı hastalar retrospektif olarak analiz edildi. Tüm hastaların yaş, cinsiyet, etiyoloji, tutulan taraf, spastisite varlığı, fonksiyonel ambulasyon seviyeleri (FAS), üst ve alt ekstremite Brunnstrom evreleri kayıt edildi. Tüm hastaların yatış sırasındaki tam kan sayısı ve alt parametreleri, beyaz küre (WBC), eritrosit dağılım genişliği (RDW), platelet dağılım genişliği (PDW), ortalama platelet volüm (MPV) ile akut faz reaktanları, eritrosit sedimentasyon hızı (ESR), C-reaktif protein (CRP) kayit edildi.

Bulgular: Çalışmamıza 32-85 yaş aralığında 55 erkek (\% 63.2), 30 kadın (\% 34.5) hasta dahil edildi. Hastaların \% 64’ü 1 yıldan kısa süre inme tanılı, \% 86.2'si iskemik, \% 50.6'sı sağ taraf tutulumlu idi. Hastaların \% 25.3'ünde spastisite yoktu. Spastisite gözlenenler içinde en sık \% 23 oranı ile Ashworth evre 1 spastisite gözlendi. Fonsiyonel düzeyleri en sık \% 20.7 oranı ile FAS 3, üst ekstremite \% 32.2 oranı ile Brunnstrom evre 3, alt ekstremitede \% 28.7 oranı ile Brunstrom evre 5 seviyede idi.

Sonuç: İnflamasyon parametreleri inmeli hastalarda fonksiyonel seviye hakkında bilgi vermektedir. İnflamatuar reaksiyonu tetikleyen sistemik inflamasyonu veya nöronal yolların inhibisyonu inme hastalarında gelecekteki potansiyel tedavi hedefleridir.

Anahtar Kelimeler: İnme, nöroinflamasyon, fonksiyonel seviye

\section{Gİìis}

İnme beyine giden kanın aniden kesintiye uğraması sonucunda gelişir. Ani olarak ortaya çıkar. Tüm dünyada kanser ve kalp hastalıklarından sonra en sık ölüm nedenidir. Ayrıca önlemler alınmaz ve erken müdahale edilmez ise ciddi bir sakatlık nedenidir. Genel olarak damar hastalıklarının tüm nedenleri beyin damar hastalıkları için risk faktörleridir. İleri yaş, kilolu olmak, yüksek tansiyon, şeker hastalığı, sigara, kolesterol yüksekliği, kalp hastalıkları, ritm bozukluğu gibi nedenler inme için en önemli risk faktörleridir. İnflamasyon iskemik inme ve diğer iskemik beyin zedelenmelerinin patogenezinde önemli bir rol oynar. Artan kanitlar, inflamatuar cevabın iki zamanlı keskin bir kılıç olduğunu göstermektedir, çünkü inmenin akut aşamasında

$\begin{array}{ll}\text { İletişim: } & \begin{array}{l}\text { Dr. Tuba Tülay KOCA, KSÜ Tip Fakültesi Fiziksel Tip ve } \\ \text { Rehabilitasyon AD, Kahramanmaraş }\end{array} \\ \text { DOI: } & \mathbf{1 0 . 1 7 5 1 7 / k s u t f d . 4 5 5 2 4 6}\end{array}$

\section{Abstract}

Objective: Inflammation has a crucial role in the pathogenesis of stroke, and in recent years, complete blood parameters and their derivatives have led to poor prognosis in the course of various diseases. We aimed to elucidate the relation of various whole blood parameters and derivatives with the functional levels of stroke patients.

Matherial and Methods: Patients diagnosed with stroke in our clinic between 2016 and 2017 years were retrospectively analyzed. All patients were recorded for age, gender, etiology, involved side, spasticity, functional ambulatory scale (FAS), upper and lower extremity Brunnstrom grades. Acute phase reactants, erythrocyte sedimentation rate (ESR), C-reactive protein (RBC), and complete blood count and sub-parameters of all patients at the time of admission, white blood cell (WBC), erythrocyte distribution width (RDW), platelet distribution width (PDW), mean platelet volume reactive protein (CRP) were recorded.

Results: Fifty-five (55) male (63.2\%) and 30 female (34.5\%) were included in the study at the age range of 32-85 years. Sixty-four percent (64\%) of the patients were diagnosed with stroke for less than 1 year, $86.2 \%$ was ischemic, and $50.6 \%$ was right-sided. There was no spasticity in $25.3 \%$ of the patients. Ashworth grade 1 spasticity was the most frequently observed in $23 \%$ of the cases with spasticity. Functional levels were most frequently with a ratio of $20.7 \%$ FAS 3 , upper extremity with a ratio of $32.2 \%$ was Brunnstrom grade 3 , at lower extremity was Brunstrom grade 5 with a ratio of $28.7 \%$.

Conclusion: Inflammatory parameters provide information about the functional level in stroke patients. Systemic inflammation that triggers an inflammatory reaction or inhibition of neuronal pathways is a potential future therapeutic target in stroke patients.

Key Words: Stroke, neuroinflammation, functional level

sekonder beyin hasarını artırmaz, aynı zamanda inme sonrası beyin iyileşmesine de faydalı olur (1).

Son y1llarda tam kan parametre ve türevleri çeşitli hastalıklarda (migren, diyabet, kardiyovasküler, şizofreni, otoimmun hastalıklar) hastalığın seyrinde kötü prognoz kriteri olarak yol gösterici bulunmaktadır $(2,3)$.

Hem konjenital hem de akkiz bağışıklık sistemlerinden gelen inflamatuvar hücreler, iskemik inme ile ilintili inflamasyonda yer alır (interleukin-17A (IL17A) etkisi ile bağlantılı işlemler). İnflamatuar hücreler inflamasyonu desteklese de, $\mathrm{T}$ düzenleyici hücreler (Tregs) iskemik hasarın erken aşamalarında koruyucu bir işleve sahip olabilir, ancak daha sonraki aşamalarda

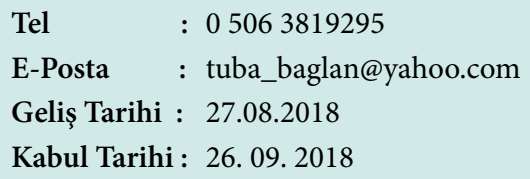


olumsuz bir rol oynayabilir. Bununla birlikte, özellikle iskemik inmede inflamasyonun kesin mekanizması bilinmemektedir; daha fazla anlaşılması, iskemik inmenin önlenmesi ve tedavisi için yeni fikirler sağlayabilir (4).

IL-6 veya C-reaktif proteingibi sistemik inflamatuar belirteçlerin yükselmiş kan seviyeleri, olumsuz fonksiyonel sonuç ve inme sonrası artan mortalite ile ilişkilidir. Hayvan çalışmaları, sistemik inflamasyon ve iskemik beyin hasarı arasında nedensel bir ilişki olduğunu göstermiştir. Sistemik inflamasyonu kötü sonuçlarla ilişkilendiren mekanizmalar arasında serebral korteksin artan nötrofil infiltrasyonu, kan-beyin bariyerinin bozulması, doku reperfüzyonunun bozulması, artmış trombosit aktivasyonu ve mikrovasküler koagülasyon ve komplemente bağlı beyin hasarı sayılabilir (5).

Nöroinflamasyon inme patogenezinde çok önemli bir role sahiptir. Son yıllarda gelişen nöroinflamasyona yeni bakıș açıları, santral sinir sistemi (SSS) hastalıklarını zayıflatmak için potansiyel terapötik hedefleri araştırmak için heyecan verici firsatlar sunmaktadır. Burada çeşitli tam kan parametre ve türevlerinin inme'li hastaların fonksiyonel seviyeleriyle ilişkisini ortaya koymayı amaçladık.

\section{GEREC VE YÖNTEMLER}

Fiziksel Tip ve Rehabilitasyon kliniğimizde 20162017 yılları arasinda yatarak tedavi gören inme tanılı hastalar retrospektif olarak analiz edildi. Tüm hastaların yaş, cinsiyet, inme etiyolojisi, tutulan taraf, spastisite varlığı, fonksiyonel ambulatuvar seviye (FAS), üst ve alt ekstremite Brunnstrom evreleri kayıt edildi. Tüm hastaların yatıs sırasındaki tam kan ve alt parametreleri, beyaz küre (WBC), eritrosit dağılım genişliği (RDW), platelet dağılım genişliği (PDW), ortalama platelet volüm (MPV) ile akut faz reaktanları, eritrosit sedimentasyon hızı (ESR), C-reaktif protein (CRP) kayıt edildi. Bilinen inflamatuvar hastalık, malignite, enfeksiyon, geçirilmiş yakın dönemde cerrahi öyküsü olanlar çalışmaya dahil edilmedi. Çalışmada Helsinki Deklerasyon kriterlerine uyuldu, retrospektif olduğu için etik kurul onayı alınmadı.

\section{İstatistik}

İstatistiksel analizler için SPSS 17 (Windows için SPSS İstatistikleri, Sürüm 17.0, Chicago: SPSS Inc., ABD) kullanılmıştır. Çalışmanın yaş ve cinsiyet değerleri ortalama ve standart sapma olarak verildi. Dağılım analizi için Kolmogorov Smirnov testi kullanıldı. Normal dağılımlı verilerin karşılaştırılmasında student $\mathrm{t}$ test; parametrik olarak dağılmayan değişkenler için medyanların karşılaştırılması için Mann-Whitney U testi kullanıldı. Korelasyon için Spearman korelasyon testi kullanıldı. İstatistiksel eşik p $<0.05$ olarak kabul edildi.

\section{BULGULAR}

Calıșmamıza 32-85 yaș aralığındaki 55 erkek (\% 63.2), 30 kadın (\% 34.5) hasta dahil edildi. Hastaların \% 64'ü 1 yıldan kısa süre inme tanılı, \% 86.2'si iskemik, \% 50.6'sı sağ taraf tutulumlu idi. Hastaların \% 25.3'ünde spastisite yoktu. Spastisite gözlenenler içinde en sık \% 23 oranı ile Ashworth evre 1 spastisite gözlendi. Fonksiyonel düzeyleri en stk \% 20.7'si FAS 3, üst ekstremite \% 32.2'si Brunnstrom evre 3, alt ekstremite \% 28.7'si Brunstrom evre 5 seviyede idi (Tablo 1).

Tablo 1: Calışmaya katılan hastaların demografik verileri ve fonksiyonel düzeyleri

\begin{tabular}{|c|c|}
\hline $\begin{array}{l}\text { Cinsiyet } \\
\text { Erkek/kadın }\end{array}$ & $\begin{array}{l}N \\
55 / 30 \\
\end{array}$ \\
\hline İnme Tipi & \\
\hline İskemik/hemorajik/diğer & $75 / 10 / 0$ \\
\hline Brunnstrom üst ekstremite & \\
\hline 1 & 25 \\
\hline 2 & 7 \\
\hline 3 & 27 \\
\hline 4 & 12 \\
\hline 5 & 13 \\
\hline Brunnstrom alt ekstremite & \\
\hline 1 & 4 \\
\hline 2 & 12 \\
\hline 3 & 20 \\
\hline 4 & 24 \\
\hline 5 & 25 \\
\hline Tutulan taraf & \\
\hline Sol/săg & $40 / 44$ \\
\hline Süre & \\
\hline$<1$ yal & 64 \\
\hline $1-2 y u l$ & 10 \\
\hline $2-5 y i l$ & 7 \\
\hline$>5 y a l$ & 4 \\
\hline $\begin{array}{l}\text { Fonksiyonel ambulasyon sinifla } \\
\text { masi }\end{array}$ & \\
\hline 0 & 14 \\
\hline 1 & 14 \\
\hline 2 & 12 \\
\hline 3 & 18 \\
\hline 4 & 10 \\
\hline 5 & 17 \\
\hline $\begin{array}{l}\text { Spastisite, Modifiye Ashworth } \\
\text { skalası }\end{array}$ & \\
\hline 0 & 22 \\
\hline 1 & 20 \\
\hline 2 & 20 \\
\hline 3 & 19 \\
\hline 4 & 1 \\
\hline
\end{tabular}


Laboratuvar verileri $\quad \mathrm{CRP}=9.2 \pm 16.6 \mathrm{mg} / \mathrm{L} \quad(0$ -

5); $\quad \mathrm{ESR}=23.2 \pm 13.8 \mathrm{~mm} / \mathrm{saat}(0-20) ; \mathrm{RDW}=15.6 \pm 6.8$

$\% \quad$ (\%11,5-\%14,5); PDW=22.8 \pm 15.2 fL (9.0-14.0); MPV=9.6 \pm 1.5 fL $(7.5$ - 11.5) idi. FAS düzeyleri, ESR $(p=0.005)$ ve $W B C(p=0.025)$ ile negatif; MPV ile pozitif ilişkili ( $\mathrm{p}=0.043)$ bulundu (Şekil 1).

Şekil 1. FAS düzeyleri ile ESR ilişkisi

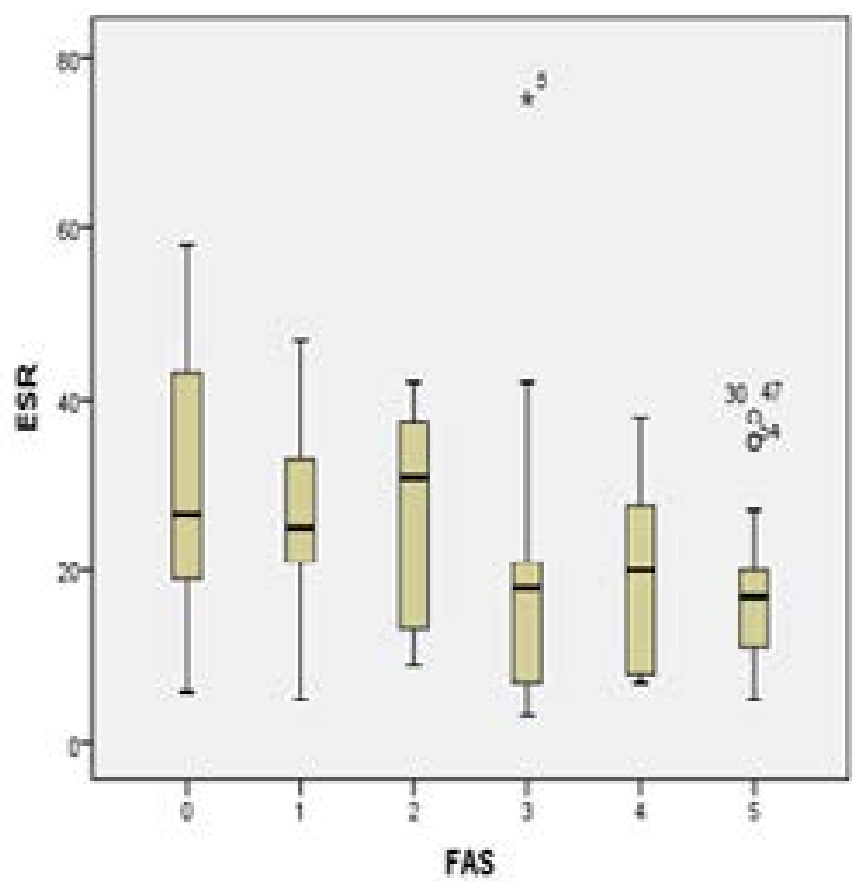

Spastisite skoru, CRP $(\mathrm{p}=0.018)$ düzeyleri ile negatif ilişkili bulundu (Şekil 2). Grubu cinsiyet yönünden iki gruba ayırdığımızda spastisite $(\mathrm{p}=0.025)$ erkekler aleyhine anlamlı yüksekti (Sekil 3). Üst/alt ekstremite Brunnstrom evrelemesi $(\mathrm{p}=0.00 / \mathrm{p}=0.033)$ kadınlar aleyhine anlamlı farklı bulundu (Şekil 4).

\section{Sekil 2. Spastisite ve CRP iliskisi}

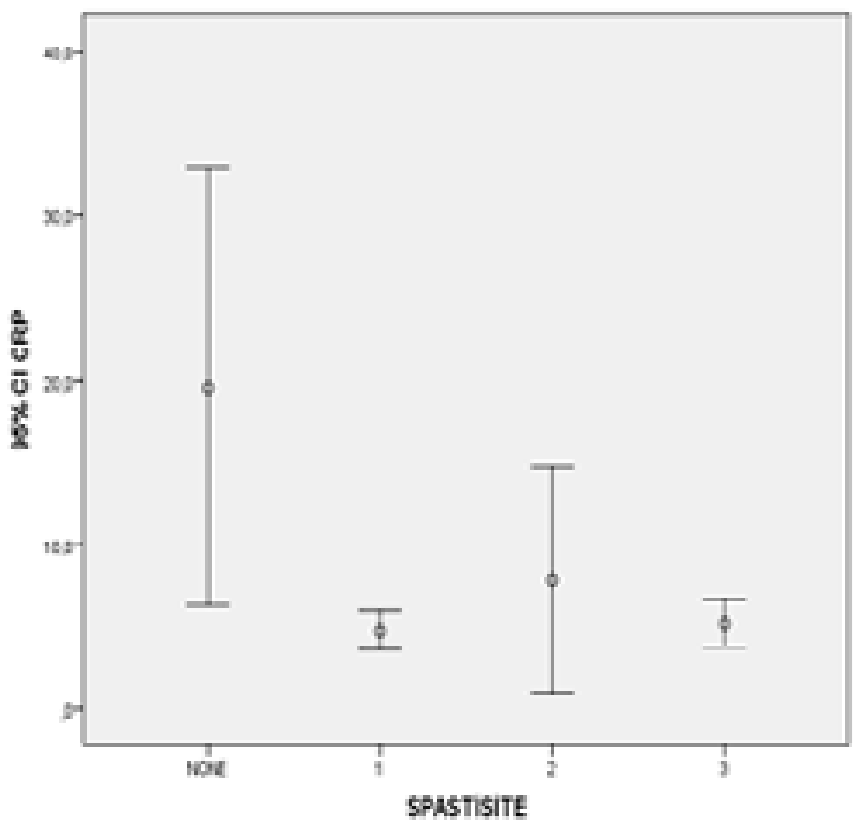

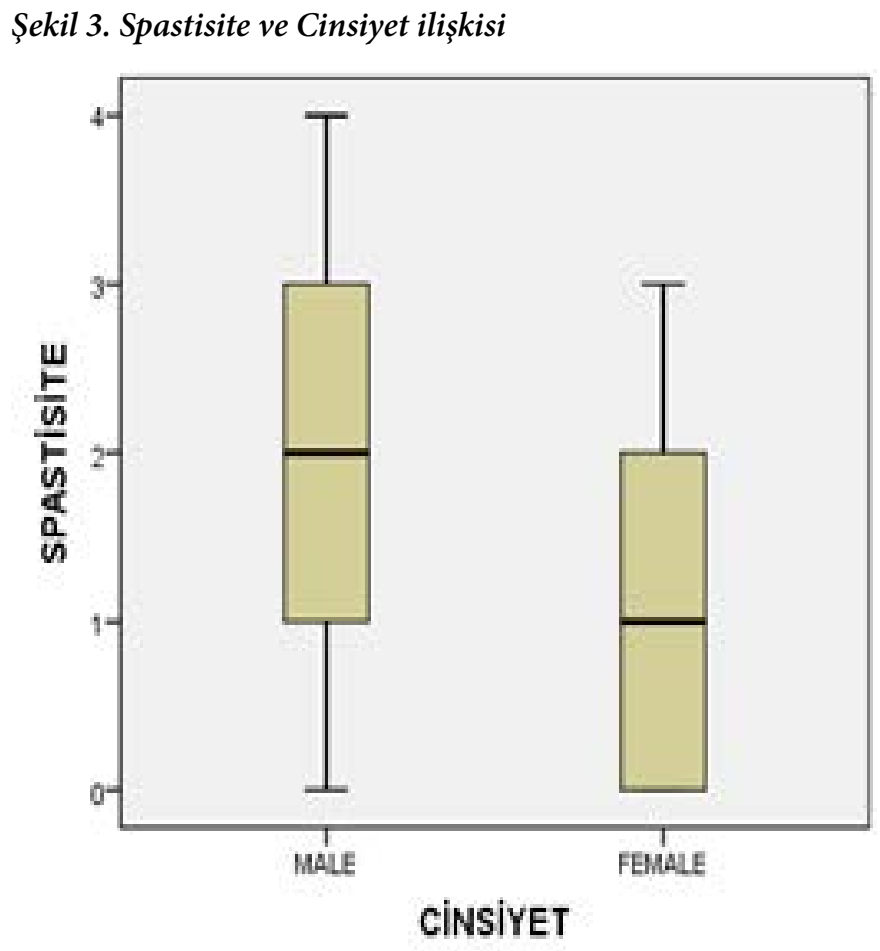

Şekil 4: Cinsiyet ile Brunnstrom evresi ilişkisi

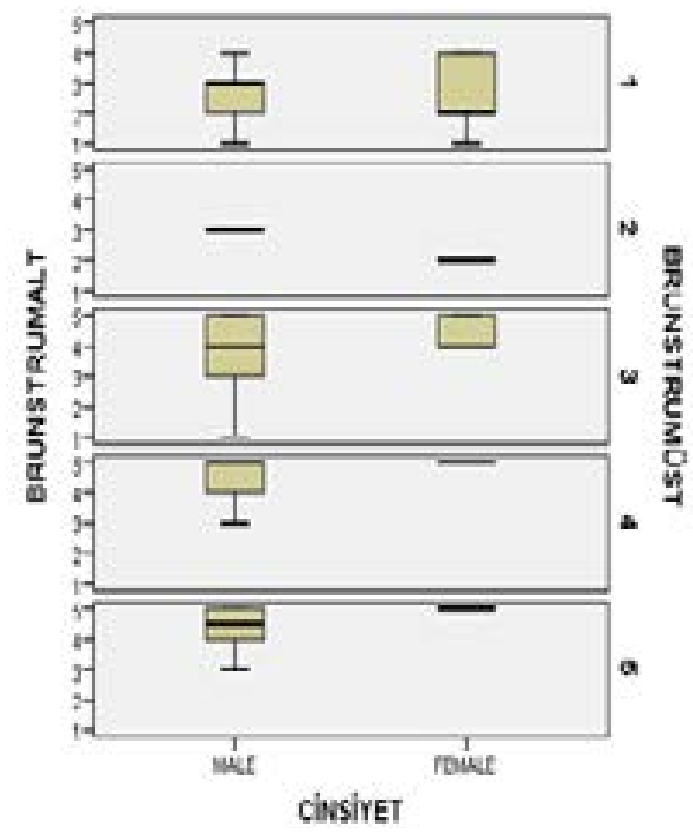

TARTIŞMA

İnme, dünya çapında morbidite ve mortalitenin önde gelen bir nedeni olduğundan, büyük bir sağllk yüküdür. Kan akışının restorasyonu, tromboliz veya endovasküler trombektomi ile tek etkili tedavidir, ancak zaman kısıtllı $\breve{g}_{1}$ ve teknolojiye erişim nedeniyle hastaların sınırlı bir oranı ulaşabilmektedir. Son yirmi yılda, serebral iskemiyi takiben nöron ölümüne yol açan temel mekanizmalar araştırılmıştır. Bununla birlikte, inme sırasında nöroprotektif paradigmaların kullanımı, deneysel araştırmalardan klinik uygulamaya çeviri başarısızlığında belirgin olmuştur. Son birkaç yılda, beyin lezyonlarının ve nörolojik defisitlerin gelişiminde önemli bir faktör olan akut serebral iskemiye karşı bağışıklık 
tepkisine odaklanılmıştır (6).

Nöroinflamasyon,

SSS'nin homeostasisin bozulması ve tüm nörolojik hastalıklara karşı yanıtıdır. SSS'nin ana reaktif bileşenleri arasında mikrogliyal hücreler ve infiltre edici miyeloid hücreleri, astrositler, oligodendrositler ve kan-beyin bariyeri, sitokinler ve sitokin sinyalleri bulunur. Nöroinflamatuar yanıtlar, nöroinflamasyon ile ilişkili mekanizmalar nöropatolojik süreçlerin yanı sıra normal beyin gelişiminde rol oynadığı için yararlı veya zararlı olabilir. Microglia, embriyonik gelişimde çok erken SSS'ye girer ve bu nedenle hem sağlıklı hem de hastalıklı beyinde önemli bir rol oynar (6, 7).

Nöroinflamasyon, iskemik inme sonrası patolojik kaskadın merkezidir. İskemik inmede ilk inflamasyon olayı, mikroglia aktivasyonu olup, çoklu reseptör sinyalleme yolakları yoluyla etki eden hem pro hem de anti-enflamatuar medyatörlerin üretimine yol açar. Mikroglia'nin hem pro- hem de anti-inflamatuar yanıtlara nasıl yol açabileceğini anlamak, iskemik inmede immünomodülatör girişimleri kullanarak terapötik stratejileri uygulamak için gerekli olabilir (8). İnvazif olmayan moleküler görüntüleme yöntemleri, temporal dinamiklere ve inme içindeki belirli nöroimmun etkileşimlerin rolüne kritik bakış açıları sağlama potansiyeline sahiptir (9).

İnme sonrası anahtar inflamatuar süreçler, yerleşik glial hücrelerin aktivasyonunu ve ayrıca dolaşan lökositlerin işgalini içerir. İnme için anti-inflamatuar stratejiler üzerine yapılan son araştırmalar, periferik immün hücrelerin damardan beyin parenkimasına transendotelyal göçünü sınırlamaya odaklanmıştır. Bununla birlikte, hastalarda yapılan serebral lökosit infiltrasyonunun blokajınıtesteden son çalıșmalar,tutarsız sonuçlar bildirmektedir. $\mathrm{Bu}$, bağışıklık hücrelerinin kan-beyin ara yüzeyinde nasıl düzenlendiğini ve beyin parankimi içine nasıl girildiğini ve özellikle de meninksler ve koroid pleksusu dahil olmak üzere lökositler için alternatif serebral infiltrasyon yollarını da göz önünde bulundurmak gerektiğini vurgulamaktadır. Bağışıklık hücrelerinin bu alternatif yollar aracılığıyla beyne nasıl göç ettiklerini anlamak, anti-inflamatuar inme terapileri için daha etkili yaklaşımlar geliştirme potansiyeline sahiptir $(6,7)$. Memeli kan-beyin bariyerinin selektif kan damarlarını kaplayan inflamatuar hücrelerin ve endotelyal hücrelerin çeşitli alt sınıfları arasındaki etkileşim, SSS'nin inflamatuar koşullar sırasında önemlidir $(10,11)$.

Son yıllarda, tam kan parametreleri ve türevleri, çok çeşitli hastalıklarda hastalıkların şiddetini göstermede bize rehberlik etmektedir. Kırmızı hücre dağılım genişliği (RDW), anizositoz olarak da bilinen bir durum olan eritrosit hacminin heterojenliğini gösteren bir ölçümdür. RDW son çalışmalarda inflamatuar durumların yanı sıra arteriosklerotik kardiyak hastalıklarda arttığ gösterilmiştir (12-14). Nötrofil lenfosit oranı (NLR) genellikle nötrofil sayısının periferal kan örneklerinde lenfosit sayısına bölünmesiyle hesaplanır; bazen tümör dokusu gibi infiltre doku hücrelerinden elde edilebilir. $\mathrm{Bu}$ oran birçok hastalık için subklinik bir inflamasyon göstergesi olarak kullanılmıştır. RDW ve NLR, önemli tam kan sayımı parametrelerinden biridir $(15,16)$.
Çalışmamızda literatürdeki yayınları destekler nitelikte inmeli hastalarımızda akut faz reaktanlarını anlamlı yüksek bulduk ve kendi içlerinde hastaların fonksiyonel düzeyleri ile anlamlı ilişkili bulduk. İnmeli hastalarda serebral iskemiden sonra, hasar yerinde inflamatuar hücrelerin (makrofajlar, nötrofiller, monositler) görülmesi, inme patogenezinde inflamasyonun rolünü gündeme getirmiștir. Geliştirilen tekniklerle; sitokinler, kemokinler, lökositler ve adhezyon molekülleri gibi çok sayıda inflamatuvar mediyatör, iskemik doku ve çevresinde gösterilmiştir (17). İskemik beyin hasarında, inflamasyon hem hastalık patogenezinde hemde klinik seyir ve prognozda rol oynayan bir faktör olarak önem kazanmaktadır. İskemik beyin hasarına ikincil akut faz cevabi, eritrosit sedimentasyon hızı yüksekliği veya fibrinojen yüksekliği ile tespit edilmektedir (18). Çalışmamızda spastisite ile CRP ve FAS ile ESR, WBC arasındaki negatif ilişkiyi akut flask dönemdeki hastalarda inflamasyonun yüksek olmasina bağlıyoruz. Akut dönemdeki hastalarımızda inflamasyon yüksek olması beklenen bir durumdur ve bu dönemde henüz spastisite gelişmemiş ve fonksiyonel ambulasyon düzeyleri düşüktür.

\section{Çalışmanın limitasyonu}

- Çalışmaya iskemik ve hemorajik tip inme tanılı hastaların dahil edilmesi

- Kontrol grubunun olmayışı

- Örneklem küçüklüğü

- Akut dönemde bu hastaların değerlendirilmesindeki zorluk

Sonuç: İnflamasyon parametreleri inmeli hastalarda fonksiyonel seviye hakkında bilgi vermektedir. İnflamatuar reaksiyonu tetikleyen sistemik inflamasyonu veya nöronal yolların inhibisyonu inme hastalarında gelecekteki potansiyel tedavi hedefleri olacaktır.

\section{KAYNAKLAR}

1. Jin R, Liu L, Zhang S, Nanda A, Li G. Role of inflammation and its mediators in acute ischemic stroke. J Cardiovasc Transl Res. 2013; 6: 834-51.

2. Perıstein TS, Weuve J, Pfeffer MA, Beckman JA. Red blood cell distribution width and mortality risk in a community-based prospective cohort. Arch Intern Med. 2009; 169: 588-94.

3. Sanmartí R, Gómez-puerta JA. [Biomarkers in rheumatoidarthritis]. Rheumatol Clin. 2011; 6S3: S25-8.

4. Pei J, You X, Fu Q. Inflammation in the pathogenesis of ischemic stroke. Front Biosci (Landmark Ed). 2015; 20: 772-83.

5. Dziedzic T. Systemic inflammation as a therapeutic target in acute ischemic stroke. Expert Rev Neurother. 2015; 15: 523-31.

6. Benakis C, Llovera G, Liesz A. The meningeal and choroidal infiltration routes for leukocytes in stroke. Ther Adv Neurol Disord. 2018; 11: 1756286418783708.

7. Ransohoff RM, Schafer D, Vincent A, Blachère 
NE, Bar-Or A. Neuroinflammation: Ways in Which the Immune System Affects the Brain. Neurotherapeutics. 2015; 12: 896-909.

8. Lee Y, Lee SR, Choi SS, Yeo HG, Chang KT, Lee HJ. Therapeutically targeting neuroinflammation and microglia after acute ischemic stroke. Biomed Res Int. 2014; 2014: 297241.

9. Chaney AM, Johnson EM, Cropper HC, James ML. PET Imaging of Neuroinflammation Using [11C] DPA-713 in a Mouse Model of Ischemic Stroke. J Vis Exp. 2018; 136. doi: 10.3791/57243.

10. Lossinsky AS, Shivers RR. Structural pathways for macromolecular and cellular transport across the blood-brain barrier during inflammatory conditions. Review. Histol Histopathol. 2004; 19: 535-64.

11. Wisniewski HM, Lossinsky AS. Structural and functional aspects of the interaction of inflammatory cells with the blood-brain barrier in experimental brain inflammation. Brain Pathol. 1991; 1: 89-96.

12. Peristein TS, Weuve J, Pfeffer MA, Beckman JA. Red blood cell distribution width and mortality risk in a community-basedprospectivecohort. Arch Intern Med 2009; 169: 588-94.
13. Salvagno GL, Sanchis-Gomar F, Picanza A, Lippi G. Red cell distribution width: A simple parameter with multiple clinical applications. Crit Rev Clin Lab Sci 2015; 52: 86-105

14. Holzınger D, Föll D. Biomarkers for chronic in flammatory diseases. Z Rheumatol. 2015; 74: 887-97.

15. Koca TT. Does obesity cause chronic inflammation? The association between complete blood parameters with body mass index and fasting glucose. Pak Jour Med Sci 2017; 33: 65-69.

16. Koca T, Arslan A, Çiledağ Özdemir F, Berk E. The importance of red cell distribution width and neutrophil-lymphocyte ratio as a new biomarker in rheumatoid arthritis. The European Research Journal, 2018. doi: 10.18621/eurj.376346

17. Kutluk K. Patogenez. Kutluk K, editör: İskemik inme. Nobel Tip Kitapevi, İstanbul, 2004: 19-35.

18. Öztürk Ş. İnmede biyolojik ve elektrofizyolojik tanı özellikleri. Balkan S, editör. Serebrovasküler Hastalıklar. Güneş Kitabevi, Antalya, 2005, 263-288. 